\title{
THE PHYSICAL DEVELOPMENT AND FUNCTIONAL STATE AS THE IMPORTANT COMPONENTS OF THE STUDENTS' HEALTH
}

D0l: 10.36740/WLek201912115

\author{
Kostiantyn V. Prontenko' , Grygoriy P. Griban ${ }^{2}$, Alla I. Aloshyna ${ }^{3}$, Sergii M. Bezpalyi', Tetiana Ye. Yavorska ${ }^{2}$, \\ Serhii M. Hryshchuk2, Pavlo P. Tkachenk0 ${ }^{5}$, Dmytro 0. Dzenzeliuk ${ }^{6}$, Ihor G. Bloshchynskyi ${ }^{7}$ \\ 1S. P. KOROLIOV ZHYTOMYR MILITARY INSTITUTE, ZHYTOMYR, UKRAINE \\ 2ZHYTOMYR IVAN FRANKO STATE UNIVERSITY, ZHYTOMYR, UKRAINE \\ ¿LESYA UKRAINKA EASTERN EUROPEAN NATIONAL UNIVERSITY, LUTSK, UKRAINE \\ ${ }^{4}$ NATIONAL ACADEMY OF INTERNAL AFFAIRS, KYIV, UKRAINE \\ 5ZHYTOMYR NATIONAL AGROECOLOGICAL UNIVERSITY, ZHYTOMYR, UKRAINE \\ 'ZZHYTOMYR ECONOMIC AND HUMANITARIAN INSTITUTE OF THE HIGHER EDUCATIONAL INSTITUTION «UNIVERSITY OF UKRAINE», \\ ZHYTOMYR, UKRAINE \\ ${ }^{7}$ BOHDAN KHMELNYTSKYI NATIONAL ACADEMY OF THE STATE BORDER GUARD SERVICE OF UKRAINE, KHMELNYTSKYI, UKRAINE
}

\begin{abstract}
Introduction: The level of health and physical fitness of the students of Ukrainian higher educational institutions has worsened in recent years. It conditions the search for effective solutions to this problem and determines the significance of the investigation.

The aim: To investigate the level of physical development and functional state of the students of agricultural educational institutions during study.

Materials and methods: The investigation was conducted in Zhytomyr National Agroecological University in 2016-2018. Seventy three students (38 male and 35 female students) took part in the investigation. The level of physical development and functional state of students was defined according to the next tests: body length, body weight, wrist dynamometry, lung capacity, heart rate, systolic and diastolic blood pressure. The level of students' physical health was examined according to the methodology by G. L. Apanasenko and determined the interrelation of the levels of physical health of the students of different genders during the investigation.

Results: It is determined that the majority of the students' investigated indicators are not improved during the first and the second years of study $(p>0.05)$. The level of the students' physical health remained unchanged during study. Moreover, the health level of both male and female students is rated as low during all stages of the investigation. Conclusions: The conducted analysis proves the necessity of the current physical education system improvement at Ukrainian higher educational institutions in order to improve the students' physical development and functional state, health and efficiency of the educational and future professional activity.
\end{abstract}

KEY WORDS: physical education, physical development, functional state, health, students

Wiad Lek 2019, 72, 12 cz. I, 2348-2353

\section{INTRODUCTION}

The works of many scientists $[1,2,3]$ mention that the level of physical development, health and physical fitness of the students of Ukrainian higher educational institutions has worsened significantly in the recent years and the majority of them have health problems. Therefore, the works of $A$. V. Mahlovany, V. S. Muntian and other authors $[4,5,6]$ mention that the physiological age of the 20-24-yearsold students exceeds the real one by 10-15 years. The investigations of G. L. Apanasenko [7] determine that the percentage of the male population who are in the safe zone of health level was decreased from 8 to $1 \%$ in the last 20 years in Ukraine. The works of S. M. Futornyi, G. M. Budagiants and other scientists $[3,8,9]$ mention that the number of students who have low and below the middle levels of somatic health was increased from $59 \%$ in 2007 to $83 \%$ in 2014 .
E. G. Bulich, I. V. Muravov, M. S. Goncharenko, V. Y. Novykova and other scientists $[1,2,5,10]$ consider that the low level of health and physical fitness of students is conditioned by the low level of physical development and health of school graduates; lack of the students' interest, motives and need of traditional classes in physical education; insufficient health-promoting and training orientation of the means of physical education; studying conditions in the modern higher educational institutions that are characterized by increased studying capacity, low level of students' activity and their lifestyle.

The scientists $[3,10]$ consider that the students' physical activity should be increased during studying in order to improve the level of their physical fitness, development and health. Physical education is an indivisible component of the formation of developed harmoniously modern specialist $[4,11,12]$. The systematic physical activity is proved to 
Table 1. The dynamics of the students' physical development and functional state indicators during the first and the second years of study at an agricultural higher educational institution $(n=73, X \pm m)$

\begin{tabular}{|c|c|c|c|c|c|}
\hline \multirow{2}{*}{ The indicators examined } & \multicolumn{4}{|c|}{ Terms of study } & \multirow{2}{*}{ Significance value } \\
\hline & $1^{\text {st }}$ & $2^{\text {nd }}$ & $3^{\text {rd }}$ & $4^{\text {th }}$ & \\
\hline \multicolumn{6}{|c|}{ Male students $(n=38)$} \\
\hline Body length, sm & $176.2 \pm 1.43$ & $176.5 \pm 1.45$ & $176.9 \pm 1.46$ & $177.1 \pm 1.42$ & $p>0.05$ \\
\hline Body weight, kg & $71.9 \pm 1.38$ & $72.3 \pm 1.39$ & $72.8 \pm 1.42$ & $73.4 \pm 1.44$ & $p>0.05$ \\
\hline Handgrip test, kg & $38.9 \pm 0.73$ & $39.4 \pm 0.69$ & $40.3 \pm 0.67$ & $40.7 \pm 0.65$ & $p>0.05$ \\
\hline Lung capacity, ml & $4073.1 \pm 91.6$ & $4096.5 \pm 90.4$ & $4107.8 \pm 89.8$ & $4113.2 \pm 90.1$ & $p>0.05$ \\
\hline Heart rate at rest, beats/min & $73.1 \pm 0.64$ & $72.9 \pm 0.61$ & $73.0 \pm 0.67$ & $73.2 \pm 0.68$ & $p>0.05$ \\
\hline Systolic blood pressure, $\mathrm{mmHg}$ & $121.1 \pm 0.93$ & $121.6 \pm 0.91$ & $121.5 \pm 0.95$ & $121.7 \pm 0.98$ & $p>0.05$ \\
\hline Diastolic blood pressure, $\mathrm{mmHg}$ & $74.6 \pm 0.89$ & $75.9 \pm 0.88$ & $74.2 \pm 0.85$ & $74.9 \pm 0.83$ & $p>0.05$ \\
\hline \multicolumn{6}{|c|}{ Female students $(n=35)$} \\
\hline Body length, sm & $162.1 \pm 1.39$ & $162.2 \pm 1.37$ & $162.4 \pm 1.37$ & $162.9 \pm 1.38$ & $p>0.05$ \\
\hline Body weight, $\mathrm{kg}$ & $57.1 \pm 1.31$ & $58.2 \pm 1.29$ & $59.1 \pm 1.34$ & $59.8 \pm 1.30$ & $p>0.05$ \\
\hline Handgrip test, $\mathrm{kg}$ & $21.9 \pm 0.62$ & $22.5 \pm 0.57$ & $23.1 \pm 0.54$ & $22.8 \pm 0.52$ & $p>0.05$ \\
\hline Lung capacity, ml & $2827.2 \pm 84.3$ & $2855.6 \pm 82.7$ & $2881.5 \pm 83.1$ & $2914.6 \pm 83.9$ & $p>0.05$ \\
\hline Heart rate at rest, beats/min & $69.7 \pm 0.75$ & $70.2 \pm 0.72$ & $69.9 \pm 0.70$ & $70.3 \pm 0.71$ & $p>0.05$ \\
\hline Systolic blood pressure, $\mathrm{mmHg}$ & $116.2 \pm 1.05$ & $116.5 \pm 1.02$ & $116.6 \pm 0.99$ & $116.4 \pm 0.98$ & $p>0.05$ \\
\hline Diastolic blood pressure, $\mathrm{mmHg}$ & $70.9 \pm 0.76$ & $71.1 \pm 0.72$ & $71.0 \pm 0.74$ & $71.2 \pm 0.71$ & $p>0.05$ \\
\hline
\end{tabular}

promote the improvement of health, physical and mental capacity and quality of students' studying and health $[1$, $8,13,14,15]$.

\section{THE AIM}

The aim of the article is to investigate the level of physical development and functional state of the students of agricultural educational institutions during study.

\section{MATERIALS AND METHODS}

The investigation of the students' indicators of physical development and functional state was conducted in Zhytomyr National Agroecological University in 2016-2018 (during the $1^{\text {st }}-4^{\text {th }}$ terms). Seventy three students of the faculty of technology (38 male and 35 female students) took part in the investigation. The level of physical development and functional state of students was defined according to the next tests: body length, body weight, handgrip test (wrist dynamometry), lung capacity, heart rate, systolic and diastolic blood pressure. The level of students' physical health was also examined according to the methodology of the rapid qualitative assessment of the somatic health level (by professor G. L. Apanasenko [7]) based on the anthropometry indicators and the state of the cardiovascular system. The health level was evaluated in points and it included the estimation of the body mass index (the ratio of body weight to body length), life index (the ratio of lung capacity to body weight), Robinson's index (a product of heart rate and systolic blood pressure), power index (the ratio of the wrist dynamometry to body weight) and heart rate recov- ery after a standard exercise (20 squats in $30 \mathrm{sec}$ ). Besides, the interrelation of the physical health levels of the students of different genders was defined during the investigation.

The authenticity of the difference between the indicators of students at the beginning and at the end of the investigation was determined by Student's t-test and the dynamics of the indicators during studying was examined.

The methods of investigation: theoretical analysis and generalization of the scientific and methodological literature, pedagogic observation, medical and biological methods and methods of mathematical statistics.

\section{RESULTS}

The analysis of the body length showed that the indicators of both male and female students tend to insignificant increase during the first and the second years of study at an agricultural higher educational institution, but they remain approximately unchanged - the difference in body length indicators of men is $0.9 \mathrm{sm}$, women $-0.8 \mathrm{sm}$ in the $1^{\mathrm{st}}$ and the 4 th terms and it is not authentic ( $p>0.05)$ (Table 1). Body weight is a vital indicator of the physical development of students. The level and dynamics of body weight point to the conclusion on the efficiency of the physical education system at a higher educational institution. The examination of the body weight indicators proves that both male and female students have body weight gain during studying. Therefore, the body weight of male students was $71.9 \mathrm{~kg}$ in the $1^{\text {st }}$ term and $73.4 \mathrm{~kg}$ in the $4^{\text {th }}$ term, the difference is 1.5 $\mathrm{kg}(\mathrm{p}>0.05)$. The difference in the average body weight of female students in the $1^{\text {st }}(57.1 \mathrm{~kg})$ and the $4^{\text {th }}(59.8 \mathrm{~kg})$ terms is $2.7 \mathrm{~kg}$, but it is not authentic ( $p>0.05)$. The conducted 
Table 2. The dynamics of the students' physical health level during the first and the second years of study at an agricultural higher educational institution $(\mathrm{n}=73, \mathrm{X} \pm \mathrm{m}, \mathrm{points})$

\begin{tabular}{|c|c|c|c|c|c|}
\hline \multirow{2}{*}{ Groups of students } & \multicolumn{4}{|c|}{ Terms of study } & \multirow{2}{*}{ Significance value } \\
\hline & $1^{\text {st }}$ & $2^{\text {nd }}$ & $3^{\text {rd }}$ & $4^{\text {th }}$ & \\
\hline Male students $(n=38)$ & $2.31 \pm 0.54$ & $2.48 \pm 0.59$ & $2.61 \pm 0.60$ & $2.73 \pm 0.62$ & $p>0.05$ \\
\hline Female students $(n=35)$ & $3.08 \pm 0.62$ & $3.14 \pm 0.60$ & $3.22 \pm 0.58$ & $3.27 \pm 0.55$ & $p>0.05$ \\
\hline
\end{tabular}

analysis of the students' body weight proved the lack of the efficiency of the current system of physical education at a higher educational institution in the improvement of the students' physical development. The body weight indicators of both male and female students are within the age norm during studying at an agricultural higher educational institution. However, considering a downtrend of the students' body weight increase during the first and the second years of study and the lack of classes in physical education in the last years of study, the students' body weight increase in the last years of study should be stated.

The analysis of the indicators of the more powerful arm handgrip test showed that both male and female students have the equal results in the $1^{\text {st }}$ and the $4^{\text {th }}$ terms authentically ( $p>0.05)$. The examination of the dynamics of arm muscles strength indicators proves their inauthentic increase by $1.9 \mathrm{~kg}$ for men and $0,9 \mathrm{~kg}$ for women during studying $(p>0.05)$. The highest results in handgrip test of male students are recorded in the $4^{\text {th }}$ term $(40.7 \mathrm{~kg})$, of female students - In the $3^{\text {rd }}$ term $(22.8 \mathrm{~kg})$ (Table 1$)$.

The investigation of the level and dynamics of the students' institutions of lung capacity proves that the indicators of the functional abilities of the respiratory system of both male and female students remained approximately unchanged during studying (Table 1). Therefore, the lung capacity indicators of male students were just 40.1 $\mathrm{ml}$ increased ( $p>0.05$ ) during the $1^{\text {st }}$ and the $2^{\text {nd }}$ years of study and the indicators of female students were $87.4 \mathrm{ml}$ increased $(p>0.05)$ that means insufficient influence of the classes in physical education according to the current system on the improvement of the students respiratory system. The indicators of the lung capacity of both male and female students are within the age norm.

The results of the many scientists' researches $[3,10,13]$ prove that physical exercises contribute to the improvement of the cardiovascular system activity indicators: the indicators of heart rate, blood pressure are decreased and recovery processes after exercises are hastened etc. However, the analysis of the heart rate at rest showed that the indicators of the students of both groups remained unchanged authentically during studying $(p>0.05)$. The heart rate changes of the students have negative dynamics - the difference of the heart rate indicators in the $1^{\text {st }}$ and the $4^{\text {th }}$ terms of the male students is 0.1 beats per min and the female students -0.6 beats per min (Table 1 ).

The analysis of the systolic and diastolic blood pressure indicators showed that although both male and female students have the downtrend of indicators in the first and the second years of study, the difference in the average results of the $1^{\text {st }}$ and the $4^{\text {th }}$ terms is not authentic ( $>0.05$ ) (Table 1). Therefore, the systolic blood pressure indicators of the male students were $0.6 \mathrm{mmHg}$ worsened and of the male students $-0.2 \mathrm{mmHg}$ worsened; the diastolic blood pressure indicators of both male and female students were $0.3 \mathrm{mmHg}$ worsened. Additionally, the indicators of blood pressure are within the age norm.

Therefore, the analysis of the physical development and functional state indicators of the students showed that the majority of the characteristics investigated are not improved during the first and the second years of study at an agricultural higher educational institution $(p>0.05)$. Additionally, such important indicators as body weight, heart rate have the downtrend that emphasizes the lack of efficiency of the current system of physical education.

The analysis of the students' physical health level showed that the dynamics of the total points according to the methodology by G. L. Apanasenko have a positive character during the first and the second years of study, but the indicators of the $1^{\text {st }}$ and the $4^{\text {th }}$ terms of both male and female students do not differ authentically ( $p>0.05$ ) (Table 2 ).

Therefore, the total point of the male students' group was 2.31 points in the $1^{\text {st }}$ term and 2.73 points in the $4^{\text {th }}$ term; the difference is 0.42 points and it is not authentic $(p>0.05)$. The total point of the female students' group was 3.08 points in the $1^{\text {st }}$ term and 3.27 points in the $4^{\text {th }}$ term; the difference is 0.19 points and it is not authentic ( $p>0.05)$. According to the methodology by G. L. Apanasenko, the health level of both male and female students remained unchanged during all stages of the investigation and it was estimated as low.

The qualitative analysis of the physical health levels showed that the absolute majority of the students (men and women) have the low and below the middle level of health during all stages of investigation. Therefore, the percentage of the students from the male group who have the low and below the low level of physical health is $81.6 \%$ (47.4\% and $34.2 \%$ respectively) in the $1^{\text {st }}$ term, and $79 \%$ (39.5 and 39.5 $\%$ respectively) in the $4^{\text {th }}$ term (Fig. 1). The number of male students who have the middle level of physical health was increased from $13.2 \%$ in the $1^{\text {st }}$ term to $18.4 \%$ in the $4^{\text {th }}$ term. Additionally, the number of male students who have above the middle level of physical health was decreased by half (from $5.2 \%$ in the $1^{\text {st }}$ term to $2.6 \%$ in the $4^{\text {th }}$ term).

The dynamics of female students' physical health levels have a similar tendency. $54.3 \%$ female students were determined to have the low level of physical health, $31.4 \%$ - below the middle level, $11.4 \%$ - the middle level and just $2.9 \%$ above the middle in the $1^{\text {st }}$ term (Fig. 2). The percentage of female students who have a low level of physical health was 

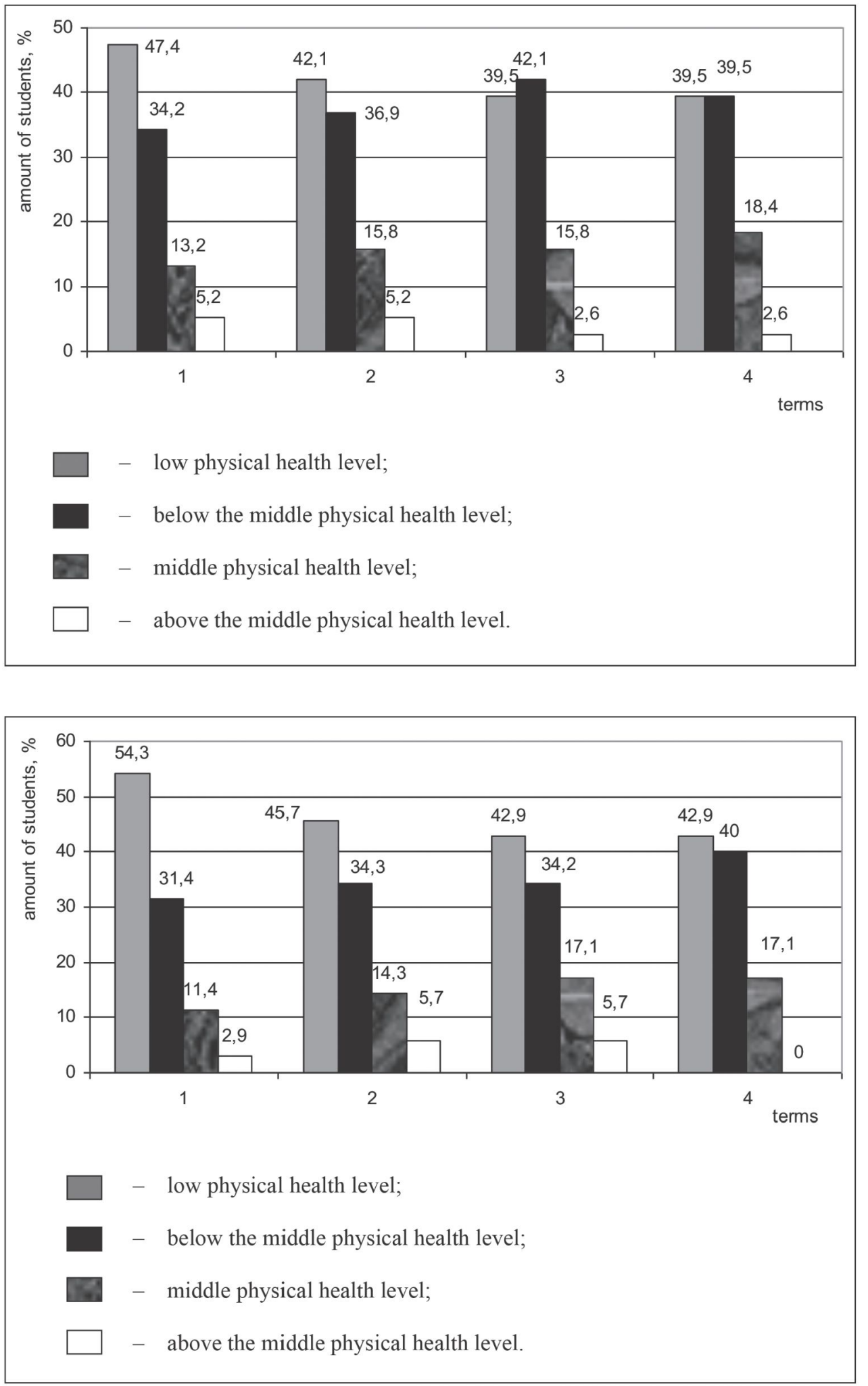

Fig. 1. The dynamics of physical health levels among male students of agrarian higher educational institutions during the first and the second years of study $(n=38, \%)$ :

- low physical health level;

- below the middle physical healthlevel;

- middle physical health level;

- above themiddle physical healthlevel.

Fig. 2. The dynamics of physical health levels among female students of agrarian higher educational institutions during the first and the second years of study $(\mathrm{n}=35, \%)$ :

- low physical health level;

- below the middle physical healthlevel; - middle physical health level; - abovethemiddle physical healthlevel.

decreased to $42.9 \%$, who have below the middle level was increased to $40 \%$ and who have the middle level was $5.5 \%$ increased (to $17.1 \%$ ) in the $4^{\text {th }}$ term. It was determined no female students who have above the middle level of physical health in the $4^{\text {th }}$ term that emphasizes the lack of the influence of the traditional classes in physical education on the physical health level of both male and female students.
It should be mentioned that neither male nor female students had a high level of physical health during study. Therefore, the analysis showed that the majority of students (more than $80 \%$ ) have low and below the low levels of physical health, more than $95 \%$ students are out of the safe zone (12 points) according to the methodology by G. L. Apanasenko. 


\section{DISCUSSION}

The World Health Organization defined approximate interrelation of different factors that ensure and form the health of a modern person, namely genetic factors (genetic heredity) - $20 \%$, environmental conditions (climate, ecological conditions) $-20 \%$, the level of health maintenance (health service support) $-8 \%$, life conditions and lifestyle (rational working, physical activity, nutrition, personal hygiene, discarding unhealthy habits $-52 \%[1,5]$. In particular, many scientists $[2,4,6,9]$ consider the conditions of life and lifestyle including various elements related to all aspects of health - physical, mental, social and psychic, to be the key factors of the students' health and working capacity improvement.

The works of many scientists $[5,10,12,14]$ mention that a great number of negative factors which cause health problems affect the students' organism systems during study. There are low physical activity, the amount of studying hours and days, emotional and mental stress, mental overloads especially during the exam terms, eating disorders (nutrition of a bad quality, poor nutrition, over nutrition and malnutrition), bad habits (smoking, abuse of alcohol, drug consumption etc) and others among them.

The world practice shows that physical activity plays an important role in health improvement and disease prevention $[1,3,8,13]$. However, the situation concerning physical education and sport is critical in Ukraine. Only $13 \%$ population is engaged in physical activity $[3,4,11]$. According to the data of many scientists $[1,2,6,10]$, the hard economic situation in post-soviet Ukraine had a negative impact on the development of physical education and popular sport at educational institutions. The number of students who belong to the physical education group with reduced exercise load and the special medical group is increasing and the number of healthy students is decreasing every year. The authors consider it to be conditioned by the lack of the traditional forms of physical education efficiency, modern students' lifestyle, low level of school graduates health. The scientists mention that the formation of a healthy lifestyle and engaging of the youth in the systematic physical activity should be one of the important areas of focus of higher educational institutions $[2,3,6,7,13,15]$.

The results of our research proved the conclusions of the works of many scientists on the insufficient level of physical development, functional abilities of the main organism systems and health of students. The investigation also shows the necessity of the improvement of the physical education system of students (men and women) in order to improve their physical state, health and efficiency of the studying and future professional activities.

\section{CONCLUSIONS}

The majority of the students' examined indicators of physical development and functional state are determined not to be improved during the first and the second years of study at an agricultural higher educational institution ( $p>0.05)$. Additionally, body weight and heart rate at rest have the downtrend that emphasizes the lack of efficiency of the current system of physical education. The level of the students' physical health remained unchanged during study according to the methodology by G. L. Apanasenko. Besides, the health level of both male and female students is evaluated as low. The analysis proves the necessity of the improvement of the system of physical education of the students at Ukrainian higher educational institutions in order to improve their physical state, health and efficiency of the studying and future professional activities.

The prospects of future investigations involve the research of the interrelation between the level of physical preparedness and the level of the students' physical health during study at higher educational institutions.

\section{REFERENCES}

1. Bulych E. Gh., Muravov Y. V. Zdorovj'e cheloveka: Byologhycheskaja osnova zhyznedejateljnosty y dvyghateljnaja aktyvnostj v ee stymuljacyy [Human health: the biological basis of vital activity and motor activity in its stimulation]. Kyev: 0lympyjskaja lyteratura; 2002 , 424 p. (Ru).

2. Ghoncharenko M. S., Novykova V. Je. Valeologhichni aspekty formuvannja zdorov'ja u suchasnomu osvitjansjkomu procesi [Valeology aspects of the formation of health in the modern educational process]. Pedaghoghika, psykhologhija ta metodyko-biologhichni problemy fizychnogho vykhovannja i sportu. 2010; 6:45-51. (Ua).

3. Hryban H. P. Zhyttiediialnist ta rukhova aktyvnist studentiv [Life activity and mobility of students]. Zhytomyr: Ruta; 2009, 593 p. (Ua).

4. Maghljovanyj A. V. Osnovy informacijnogho polja zdorov'ja osobystosti [Basics of information field of personality health]. Visnyk Chernighivsjkogho nacionaljnogho pedaghoghichnogho universytetu imeni T. Gh. Shevchenka. Serija: Pedaghoghichni nauky. Fizychne vykhovannja ta sport. 2010; 81: 285-289. (Ua).

5. MuntjanV.S. Analyz faktorov, opredeljajushhykh zdorovj'e cheloveka y okazyvajushhykh na negho vlyjanyja [Analysis of factors that determine human health and influence it]. Fyzycheskoe vospytanye studentov. 2010; 6: 44-47. (Ru).

6. Duboghaj 0. D., Aljoshyna A. I., Lavrynjuk V. Je. Osnovni ponjattja j terminy zdorov'jazberezhennja ta fizychnoji reabilitaciji v systemi osvity [Basic concepts and terms of healthcare and physical rehabilitation in the education system]. Lucjk: Volynsjkyj nacionaljnyj universytet imeni Lesi Ukrajinky; 2011, 296 p. (Ua).

7. Apanasenko G. L. Knygha o zdorovj'e [Health Book]. Kyev: Medknygha; 2007, 132 p. (Ru).

8. Futornyj S. M. Dvyghateljnaja aktyvnostj y ee vlyjanye na zdorovj'e y prodolzhyteljnostj zhyzny cheloveka [Motor activity and its effect on human health and longevity]. Fyzycheskoe vospytanye studentov. 2011; 4: 79-84. (Ru).

9. Budagh'janc Gh. M. Zdorovyj sposib zhyttja - osnovna umova profilaktyky deviantnoji povedinky pidlitka (istorychnyj aspekt) [Healthy lifestyle - the main condition for the prevention of adolescent deviant behavior (historical aspect)]. Pedaghoghika, psykhologhija ta medyko-biologhichni problemy fizychnogho vykhovannja i sportu. 2010; 6:25-28. (Ua).

10. Prysiazhniuk S., Tolubko V., Oleniev D. et al. The influence of physical activities on biological age parameters of the first-year female students from the special medical department. Journal of Physical Education and Sport. 2018; 18(2):561-564. doi:10.7752/jpes.2018.02081. 
11. Bulatova M. M. Fitnes i dvigatel'naya aktivnost': problemy i puti resheniya [Fitness and physical activity: problems and solutions]. Teoriya i metodika fizichnogo vikhovannya i sportu. 2007; 1:3-7. (Ru).

12. Prontenko K., Griban G., Prontenko V. et al. Health improvement of cadets from higher military educational institutions during kettlebell lifting activities. Journal of Physical Education and Sport. 2018; 18(1):298-303. doi:10.7752/jpes.2018.01040.

13. KrutsevychT.Yu. Teoriia i metodyka fizychnoho vykhovannia [Theory and methods of physical education]: pidruchnyk dlia stud. vuziv fiz. vykhov. isportu. T. 1. Zahalni osnovy teorii imetodyky fizychnoho vykhovannia. Kyjiv: Olimpijsjka lij'eratura; 2008, 391 p. (Ua).

14. Zavydivska 0, Zavydivska N., Khanikiants 0 . Self-management as a condition for creating a health culture among students. Journal of Physical Education and Sport. 2016; 16(1):592-597. doi:10.7752/ jpes.2016.s1093.

15. Bolotin A., Bakayev V. Structure and content of the educational technology of managing students' healthy lifestyle. Journal of Physical Education and Sport. 2015; 15(3):362-364. doi:10.7752/ jpes.2015.03054.
The investigation is conducted under the topic of the research activity of the department of physical education of Zhytomyr National Agroecological University in 2016-2020 "Theoretically methodological aspects of the improvement of the system of physical education of the students of Ukrainian higher educational institutions" (state registration number 0116U004203).

\section{Authors' contributions:}

According to the order of the Authorship

\section{ORCID numbers:}

Kostiantyn Prontenko - -0000-0002-0588-8753

Grygoriy Griban - 0000-0002-9049-1485

Alla Aloshyna - 0000-0001-6517-1984

Sergiy Bezpaliy - 0000-0002-8760-3255

Tetiana Yavorska - 0000-0001-6104-2202

Serhii Hryshchuk - 0000-0002-5553-8110

Pavlo Tkachenko - 0000-0003-4407-8611

Dmytro Dzenzeliuk - 0000-0003-1913-8571

Ihor Bloshchynskyi - 0000-0003-1925-9621

\section{Conflict of interest:}

The Authors declare no conflict of interest

\section{CORRESPONDING AUTHOR Kostiantyn Prontenko}

Department of Physical Education, Special Physical Training and Sport S. P. Koroliov Zhytomyr Military Institute, Zhytomyr, Ukraine tel: +380675069142

e-mail: prontenko-kostya@ukr.net

Received: 16.05 .2019

Accepted: 19.11.2019 